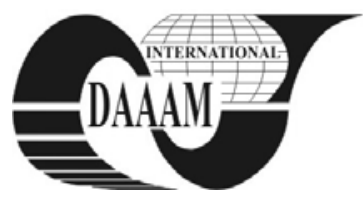

Annals of DAAAM for 2011 \& Proceedings of the 22nd International DAAAM Symposium, Volume 22, No. 1, ISSN 1726-9679 ISBN 978-3-901509-83-4, Editor B. Katalinic, Published by DAAAM International, Vienna, Austria, EU, 2011 Make Harmony between Technology and Nature, and Your Mind will Fly Free as a Bird

\title{
LIBERALIZATION AND DEVELOPMENT IN ICT SECTOR: THE CASE OF CROATIA
}

\author{
SKUFLIC, L[orena] \& MRAVAK, T[ina]
}

\begin{abstract}
ICT sector refers to a combination of manufacturing and services industries that captures, transmits and displays data and information electronically. Broad access to personal computers in business, government and households has led to rapid expansion of Internet usage, changing the way in which information is accessed and shared and business is done. Over the past ten years, and particularly in 2000's, ICT has been an engine of growth in transition economies. This paper examines the effects of liberalization of the telecommunications market in Croatia, a vital part of the ICT sector, which lagged with respect to the rest of Europe. Liberalization of the ICT sector has been important for the process of economic growth in Croatia because it resulted in lower prices, better service quality and greater choice for consumers. Best results were achieved in segments of the Internet and mobile telephony in terms of prices, and in the fixed telephony segment in terms of number of participants. However, high barriers to entry still characterise specific market segments which enables persistence of one firm as a leader.
\end{abstract}

Key words: liberalization, ICT sector, telecommunication market, internet users, monopoly, oligopoly

\section{INTRODUCTION}

Washington Consensus that was adopted for the economies in transition represents an agreement of the governments of the debtor countries and international institutions on the implementation of the neo-liberal approach in running the country, which means more emphasis on the free functioning of markets and prices without the influence of the state, liberalization of foreign trade sector and reduction of overall importance of the state in the national economy. This paper examines the effects of liberalization of the telecommunications market, which is an integral part of the ICT sector. ICT sector is defined as a combination of manufacturing and service industries, which electronically receive, transmit and display data and information. It consists of the IT sector and telecom sector. The liberalization of telecommunications markets in Europe began in 1987, when the EC proposed a gradual opening of this sector through several stages. The first was related to opening of market for the user equipment in 1988, services other than public voice services 1990, satellite communications 1994, cable television 1995 and mobile communications 1996. Full liberalization in respect of both voice telephony and telecommunications infrastructure was achieved in early 1998. These processes in Croatia lagged in respect to the rest of Europe, which consequently lead to the lag in technology and quality of services.

\section{THE ROLE OF ICT SECTOR IN THE ECONOMY}

According to OECD, ICT sector has an undeniable importance for economic growth, which has been proven in numerous studies (OECD, 2003). At the same time, the development of this sector has a direct or indirect impact on other sectors and the economy and society as a whole. The role of ICTs is reflected in their potential for reducing poverty, and especially on the impact they may have on mainstream development objectives in, for example, health, education, providing livelihoods and empowerment (David, 2004). For the development of this sector processes of liberalization are very significant. They contribute to the elimination of monopolies; increase the number of participants in the market thus increasing competition, they lead to introduction of the new products and reduce the price of services. The lack of liberalization and deregulation of such markets has negative effects for the consumers, in terms of reducing the consumer's surplus on such markets due to high prices and much lower quantities, compared to ones consumers would be paying in another, more competitive market. The abolition of the monopoly can serve as incentive for competitors to invest more in new technologies and the associated cost reductions, including reducing the price, and may result in increasing quality of services. Schumpeter stated that monopolies were useful in terms of generating innovation because additional profit provides companies with sufficient capital required for research and development and investment (Schumpeter, 1976). In four year period, since 2007 till 2011, ICT sector in Croatia created more than 7,000 new jobs and stimulated the creation of more than 200 new IT companies, which clearly demonstrates its importance (IDC, 2011). As for the current situation, the share of ICT spending was $1.7 \%$ of GDP in 2010, which indicates a decrease compared to 2007 when the share of ICT spending accounted for $2.3 \%$ of GDP. Croatia lags little behind the world average of $2.5 \%$ of GDP, but is within the regional average of Central and Eastern Europe. Studies have shown that lower investment in information technology brings with it a slower transformation of society towards a digital economy and the slow rate of change (Atkinson et al, 2002).

\section{TELECOMMUNICATION MARKET CROATIA}

This paper will be exploring the processes of liberalization of telecommunication services on the Croatian market, which moved through three phases. In the first phase the Protocol on Croatian accession to the WTO was signed, under whose auspices the processes of liberalization are taking place. In the second phase, the telecommunications services in the immovable network were open to free market competition, and since 2003 the former monopolist in that market had to provide access for other operators and service providers to unbundled local loop, and provide number portability options as well as reselection of operator options. This paper also analyzes the overall market for telecommunication services, from fixed lines, via the mobile telecommunications and the Internet.

Although the monopoly in fixed-lines was abolished (2003), the technological advancements and the daily rhythms of life had greater influence on decline in significance of the 
fixed telecommunications and increased the importance of mobile telecommunication. The liberalization of this market did not have a significant impact on the development of product and improvements in quality because there has been a change in consumer tastes and the move towards mobile telephony. In a very short time this market segment has changed from monopoly to oligopoly market with a prominent leader, whose market share exceeds $80 \%$. Liberalization of the fixed network market segment resulted in the entry of eight new operators, which in 2009 had $18.8 \%$ of the total market revenue and $26.7 \%$ of the total number of users. In 2010 the importance of business leaders has been slightly reduced, but the market can still be characterized as highly monopolized.

The shift in consumer preferences of the Croats is in line with both global and European trends, but the growth in ICT sector is far beyond the one in developed economies. According to the Croatian Agency for Post and Electronic Communications (HAKOM) and the International Telecommunications Union (ITU) in the last 10 years the number of mobile phones per 100 inhabitants increased from 22.93 in 2000 to 144.48 in 2010, an increase of $530 \%$. If this is compared to EU, in Germany this ratio increased by $117 \%$, in France by $102 \%$ and in the UK by $73 \%$, while in Southeast Europe, in the first place, Bosnia and Herzegovina with an increase of $3068 \%$ and Serbia with $170 \%$, while Slovenia has achieved a growth of $71 \%{ }^{1}$.

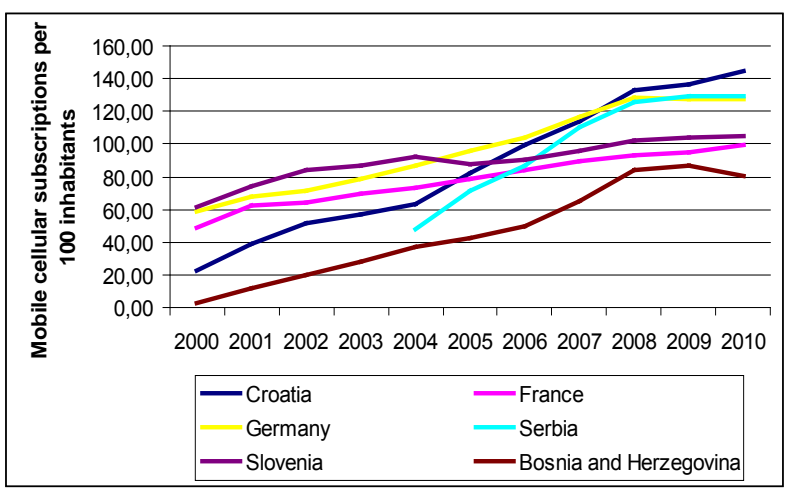

Fig. 1. Mobile phones per 100 inhabitants, 2000-2010 (HAKOM, 2011, ITU, 2011)

The reasons for this growth can be seen in the low base from which the transitional economies began to grow, given that their process of liberalization and the introduction of new technology were delayed, but also in the fact that these countries were long-closed economies, and once the boarders opened, taking into account the fact that this was an era of consumerism, a sudden "fake" growth of consumer needs emerged. Liberalization has brought the abolition of monopolies and the "competitive battle" has gone so far that leadership in this market segment has also disappeared. Penetration of second company (VIPnet) has been achieved through the introduction of prepaid system, which at the beginning brought that company market share of more than $52 \%$. As time passed by, the former monopolist slowly returned its lost dominance. Nearly half the users of mobile communication networks select the Croatian Telecom (HT), and after that VIPnet, which lags behind by only a few percentage points. Tele2, which was the last one to join this race, occupies a relatively small market share, compared with the other two operators. From market share figures it could be concluded that this is a duopoly since the HT and VIPnet together constitute $88.4 \%$ of the entire market. Analysis of pricing strategies of these operators indicates the presence of severe price war, which is confirmed by an increase in switching from one network to another of $3410 \%$ in immoveable networks and $9693 \%$ in mobile networks (HAKOM, 2011). Number of Internet users in Croatia increased from 6.64 in 2000 per capita to 60.32 in 2010, which is total growth of more than $800 \%$, but this indicator still lags behind the EU countries. In Germany, for example, in 2010, 81 out of 100 people knew how to use Internet. Research has shown that the process of liberalizing the Internet market has increased the number of users, reduced service costs, and introduced new technological solutions in infrastructure, which has still not given satisfactory results in percentage of penetration in the market. This percentage is still below the average of developed countries.

\section{CONCLUSION}

Research has shown that the process of liberalization has resulted in the entry of new companies in the telecommunications market, but barriers to entry into the segment of fixed telephony are still highly present, primarily in the area of government concessions and high costs in terms of ownership of infrastructure, which allows preserving a highly monopolistic position of HT. Generally, it can be concluded that consumers benefited because the quality of services either remained on the same level or improved, while prices continued to fall through the entire period in all segments of the telecommunications market. Lower prices, greater product diversification and quality growth are the features of the Internet market that represents the segment of fixed telephony and mobile market that has gone furthest in the process of liberalization and is moving towards monopolistic competition. Although Internet market shows the fewest imperfections, viewed through the consumer surplus, liberalization has achieved the best results in the mobile segment, where the oligopoly is present with pronounced price wars. Although less attractive for new entrants than a decade ago, the Croatian ICT sector continues to generate significant revenue for existing operators. It is likely that it will be among the last industries in Croatia to suffer from economic downturn.

\section{REFERENCES}

Atkinson, et al. (2002), The 2002 New Economy Index, Washington: PPI, www.ppionline.org Accessed:2011-10-01

David S. (2004), ICTs and Economic Growth in Developing Countries, document submitted to the POVNET for INFORMATION, OECD Development Co-operation Directorate. http://unpan1.un.org/intradoc/groups/public/do cuments/apcity/unpan022641.pdf Accessed: 2011-09-28

Schumpeter, J.A. (1976), Capitalism, Socialism and Democracy, 5th Edition. London: Allan and Unwin

Škuflić, L., Vlahinić-Dizdarević,N. (2003), The concept of the new economy and the role of information and communication technology in the Republic of Croatia Ekonomski pregled, Vol. 54, No. 5 - 6, pg. 460 - 479, ISBN 0424-7558

*** (2011) ICT Market Overview http://www.idcadriatics.com/index.php?nd=Research\&prg=ICT+Market+ Overview Accessed: 2011-10-02

*** (2003), ICT and Economic Growth, Evidence from OECD countries, industries and firms. OECD

*** (2011) International telecommunications union, www.itu.org Accessed: 2011-10-02

*** (2011) Croatian Agency for Post and Electronic Communications www.hakom.hr Accessed: 2011-10-02 